NBER WORKING PAPER SERIES

LABOR MARKET INSTITUTIONS, CONSTRAINTS, AND PERFORMANCE

Richard B. Freeman

Working Paper No. 2560

NATIONAL BUREAU OF ECONOMIC RESEARCH 1050 Massachusetts Avenue

Cambridge, MA 02138

April :988

Edward Funkhauser, Alida Castillo, and Francoise Carre provided invaluable research assistance. The research reported here is part of the HBER's research program in Labor Studies. Any opinions expressed are those of the author and not those of the National Bureau of Economic Research. Support from The Lynde and Harry Bradley Foundation is gratefully acknowledged. 


\section{Labor Market Institutions, Constraints, and Performance}

\section{ABSTRACT}

This study examines the changes in labor market institutions and outcomes across CECD countries in the past two decades and relates indlcators of the institutions to outcomes. It has four flndings. First, there has been an increased divergence in labor market institutions, with unlonisation growing or remaining at high levels of density in some countries while declining in others. Second, changes in the two major outcomes on which analysts and policymakers focus - employment and real wages - are substantially negatively correlated across countries, conditional on growth of GDP. Countries that had rapid growth of employment in the 1970 s or 1980 s, and high employment to working age population rates, such as the U.S. or Sweden, had relatlvely slow growth of real wages; while by contrast countries with relatively slow growth of employment, such as Spain, had rapid growth of real wages, indicative of a labor demand type constraint on outcomes. Third, there is a moderate nonlinear relation between labor market outcomes and instlutions: countries with either relatively centralized wage-setting (as evidenced by little inter-industry dispersion of wages) such as the Scandinavian countries and countries with decentralized wage-setting (as indicated by high inter-industry dispersion of wages) had better performances in employment than countries with intermediate types of labor market structures and institutions. Fourth, even among countries ath comparable institutions, there is a considerable diversity of performance.

Richard B. Freeman

National Bureau of Economic Research

1050 Massachusetts Avenue

Cambridge, MA 02138 
Labor Market Institutions, Constraints, and Economic Performance

The labor market experiences of advanced economies diverged sharply in the 1970s and 1980s: employment Increased In North America, Australla, and Japan while stagnating in many western European countries; real wages grew rapidly in most OECD countries but not in the United States, then generally stabilized or declined but not in the United Kingdom: Many analysts (largely European) blame Europe's stagnant employment on union policies and government labor regulations that reduce wage and employment flexibility and extol the US as the paragon of a flexible efficient market. Other observers (largely American) bemoan the slow growth of productivity and shift of jobs to low wage industries in the US and view Japan as the exemplar economy. Still other analysts blame high unemployment on decentralized wage-setting that permits real wage growth despite joblessness and see a solution In Swedish-style 'corporatism'.

Do labor market institutions in OECD countrles differ sufficlently to have caused the observed differences in economic performances of the 1970s-1980s? Do claims that labor market flexibility, unionism, centralised or decentralised wage-setting affect outcomes stand up to critical investigation?

To answer these questions I analyse data on changes in wages and employment pooled across countries and industries and relate these changes to indicators of the institutional structures of labor markets. In the first section I compare two Indicators of labor market arrangements - union density and dispersion of wages among industries - and find large differences and increasing polarization among OECD countrles, as some countries have moved to near universal unionisation/collective bargaining coverage and narrow wage differentials while others have moved to weak unionism and wider differentials. In the second section I document the existence of a substantial tradeoff between growth of employment and real wages across countries and industries. 
In the third section I relate measures of performance to labor market structure and find that economies at the extremes - with highly centralized or highy decentralised labor market arrangements - had better employment records than economies 'betwixt and between'. While this is consistent with theories that decentralized and highly structured labor markets may produce similar outcomes (Olson, 1982; Calmfors and Driffil1), there is sufficient diversity in outcomes among countries to indicate that specific institutional arrangements are neither necessary nor sufficient for adoption of employment-creating policies. I. Differences in Labor Markets: Union Density and Wage Structures

Labor market institutions, wage-setting systems, and the wage structures that reflect those systems changed in different ways in developed countries in the $1970 \mathrm{~s}$ and $1980 \mathrm{~s}$. The proportion of workers represented by unions fell in the US, Japan, and, after a period of growth, in the UK and Netherlands while increasing or stabilizing in most OECD countries. Wage differentials by industry and skill, which historically narrow with develop-ment, rose in some countries but not in those with centralized wage setting.

Union density/collective bargaining representation

Table 1 records figures on the proportion of nonagricultural wage and salary workers in the traditlonally most important labor market institution in capitalism .. trade unions. As unionism has different meanings across settings (it reflects representation at the company level and the Shunto offensive in Japan; collective bargaining to a written agreement in the US; national wagesetting in Scandinavia, etc.) and is measured differently ( 1 ), the figures should be viewed as crude indicators of patterns and changes. The question marks next to France and Italy reflect the particularly weak measures of unionisation in those countries (2), though data for other countries are also imperfect. In Australia the arbitration wage-setting system places unions at the center of wage determination despite moderate density. In the UK the drop 
Table 1: Levels and Changes in Union Density as a percent of Non Agricul tural Wage and Salary Employees Across Countries, 1970.85

Countries with Sharp Rises in Density

\begin{tabular}{|c|c|c|c|c|c|}
\hline & $\underline{1970}$ & 1979 & $1984 / 5$ & $1970-79$ & $\underline{1979-85}$ \\
\hline Denmark & 66 & 86 & 98 & +20 & +12 \\
\hline Finland & 56 & 84 & 85 & +28 & +1 \\
\hline Sweden & 79 & 89 & 95 & +10 & +6 \\
\hline Belgium & 66 & 77 & $\cdots$ & +11 & $\ldots$ \\
\hline
\end{tabular}

Countries with Moderate Rises in Density

$\begin{array}{lllllr}\text { Italy (?) } & 39 & 51 & 45 & +12 & -6 \\ \text { Germany } & 37 & 42 & 42 & +5 & 0 \\ \text { France (?) } & 22 & 28 & 28 & +6 & 0 \\ \text { Switzerland } & 32 & 36 & 35 & +5 & -1 \\ \text { Canada } & 32 & 36 & 37 & +4 & +1 \\ \text { Australia } & 52 & 58 & 57 & +6 & -1 \\ \text { New Zealand } & 43 & 46 & -5 & +3 & - \\ \text { Ireland (a) } & 44 & 49 & 51 & +5 & +2\end{array}$

Countries with Stable/Declining Density

$\begin{array}{llll}\text { Norway Kingdom } & 59 & 60 & 61 \\ \text { United Kia } & 51 & 58 & 52 \\ \text { dustria } & 64 & 59 & 61 \\ \text { Japan } & 35 & 32 & 29 \\ \text { Netherlands } & 39 & 43 & 37 \\ \text { United States } & 31 & 25 & 18 \\ & & & \\ \text { Mean } & 47 & 53 & 54 \\ \text { Standard Deviation } & 15 & 19 & 22 \\ \text { Coeficient of Variation } & 32 & 36 & 40\end{array}$

* No Change in union share of total employment due to fall in agriculture employment.

Note: Union Density as a percent of nonagricultural wage and salary employees:

Source : U.S. Department of Labor, Bureau of Labor Statistics, Office of Productivity and Technology, Division of Foreign Labor Statistics and Trade, July 1986. Center for Labour Economics CECD Data Set upated with respective Country Statistical Abstracts.

a) My figures on density Asagree with those of WK Foche and Joe Larragy (1987) because they divide union membership by labor force while I divide by employment. 
in union representation exceeds that shown in the Table because official. union statistics appear to exaggerate mentersip in the mid i980s (3). In the js private sector density plumetted to 148 in 1986 , with total density faling less becatse uniolna organized traditionally nonunion public sector workers. These and other measurement issues notwhstanding, Table 1 reveals a clear divergence in unionisation rates across countres that is anikely to change with better data. From 1970 to 1979 density zncreased in many countries, whth tises of 10 or more points in sive, but daclined in the Us, Japan, and Austra, From 1979 to 1985 denstey stabilized in most compris, but droped sharply in the US, UK, Japan, and the Netherlands. Different trends betreen comtries that form netura patrs - 10s and Canda, Belgium and the Netherands, ve and Ireland - show that the changlng unionjation

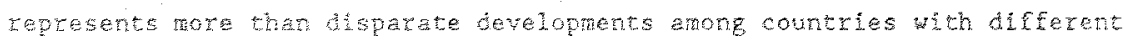

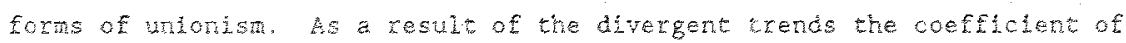


disperson of rages anorg industries

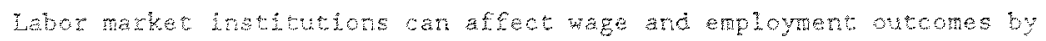

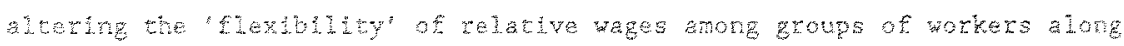
industry, thill, or other dimensions. Recent discusion of fiexhility has

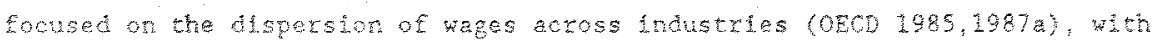

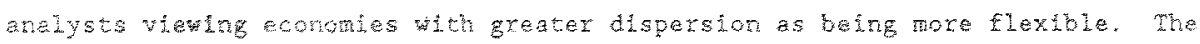

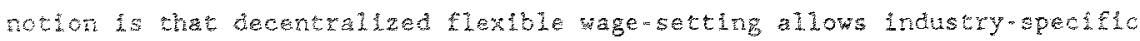
facors to producs greater industy differences than is a

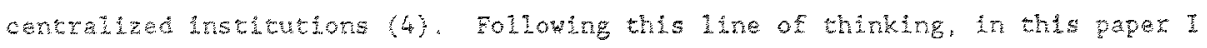
use industry wage disparion as an incleator of labot market structure. I measure disperston by standard deviatons of 1 n wages from five deta sete: the

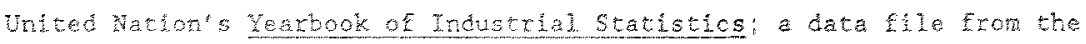

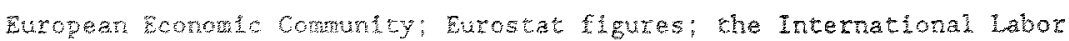




\section{Country UN $1973-83$}

Eurosta $1972-81$

$\begin{array}{lr}\text { US } & 23-28 \\ \text { Japan } & 25-26 \\ \text { Canada } & 21=25 \\ \text { Austria } & 21-27\end{array}$

$\begin{array}{ll}\text { N.Zealand } & 17-21 \\ \text { U.Kingdom } & 20-27 \\ \text { Australia } & 21-24 \\ \text { Norway } & 19-25\end{array}$

Be $\operatorname{lgiun}$

$$
25 \cdot 24
$$

Ireland

$22-21$

$19 \cdot 20$

Germany

Netherlands

- e

t

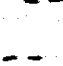

Switzerland

High/Increasing Dispersion
$28-33$

$25-28$

$25=26$

$24-25$

$24-26$

$21-22$

Increasing Dispersion

$4-20$

$16 \cdot 16$

$17-20$

- 17

$19-19$

C.

Moderate/Stable Dispersion

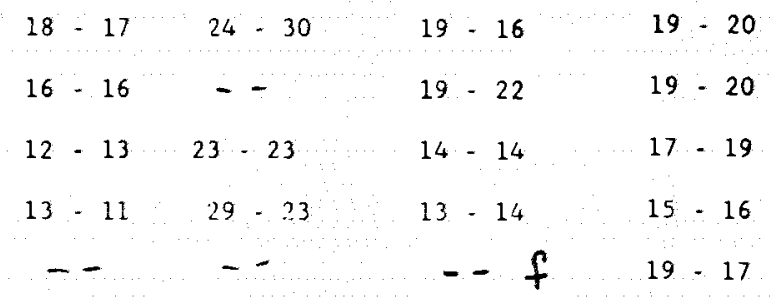

Decreasing Dispersion

Italy $\quad 32 \cdot 19$
France(?) $\quad h-$

$24-13 \cdots 48-37$

$19-10 x$

$22-13$

$16-13 \quad 34-34$

$13-14$

$15-14$

Low Dispersion

$\begin{array}{lcccccc}\text { Denmark } & 15-14 & 11-09 & 26-16 & 12-12 & 10-10 \\ \text { Sweden } & 12-13 & - & - & 09-08 & 09-09 & 9-10 \\ \text { Finland } & 17-15 & - & - & - & 14-14 & -\end{array}$


a. Data for Netherlands and Belgiur for 1985.

b. N. Zealand data from national statisical source shows increase in dispersion from $13-17$.

c. Australia Reports too few industries for results to be trustworthy.

d. Males only.

e. Netherlands has figures for 17 industries, with disp of 41 in 1973 and 29

in 1983 .

f. Switzerland figures for males, with disp of 8 in 1975 and 11 in 1984.

g. Italy's figures for 1982 based on a smallex number of industries.

h. Klau and Mittelstadt show a decline in dispersion in France from 1966 to

1982 from 155 to 133 based on data from the Swedish Employer's Federation. 
Organizations's Yearbook of Labor Statist1cs; and the US Bureau of Labor Statistlc's International Comparisons of Hourly Compensation Costs for Production Workers in Manufacturing. The data differs in several ways: UN and EEC figures are wage and salary bills divided by tocal employment; the ILO and Eurostat data are hourly earnings; while the BLS measures hourly compensation. The number of 1ndustries varles by data set and in some instances by country within a data set (5). Service 1ndustries are under-represented. As usual with international comparative data, moreover, the data trade-off comparability among countries for accuracy about any particular country. The purpose of examining several data sets is to enable me to differentlate patterns that are robust across sources and thus more $11 \mathrm{kely}$ to be valld from patterns that result from peculiaritles in a particular data set.

Table 2 summarlzes the results of my calculations, with countrles grouped by the level and change in dispersion in the 1970s-early 1980 s and with the variances multiplied by 100 for ease of presentation. Desplte differences among data, the table reveals a broad similarity in dispersion that differentiates between countries where pay is centrally determined (1.e. the Scandinavian countries) and countrles with decentrallzed wage-setting (US, Japan, etc,). The table also shows that dispersion increased in the US, Japan, Canada, New Zealand, Auscralla, and possibly Norway; decreased markedly in Italy; but did not change in most other countries. As the historic pattern is for wage differentlals to narrow or at least not 1ncrease, the rise has attracted attention (see Be11 and Freeman, 1985; Lawrence and Lawrence, 1986). The most aberrant figures are from the EEC flle, whose calculated dispersions for Italy and France are out of line with those from other sources, though showing similar changes over time, and those for Norway, which is rated high in dispersion in the UN data but low in ILO data. 


\section{other wage differentials}

As a check on the extent to wich industry wage dispersion reflects the overall wage-seteing system in a country I have also examined pay differentials by skill, sex, and age, and find that they follow patterns similar to industry differentials. Consider, for example, the patterns of change in skill premia. During the 1970 s premia by years of schooling or occupation narrowed in most developed countries, often substantially, as the influx of young educated workers created by the baby boom and post-world war II expansion of higher education reduced the pay of the more educated (Freeman, 1981). The 1980s experience has been more varied: education and white collar/manual pay ratios widened sharply in the U.S, and U.K. to pre-1970s levels while maintaining levels much narrower than in the eariy 1970 s in many other oEcD countries (Sweden, Denmark, Italy, Norway, Australia, Finland, and Japan, according to OECD, 1987b). As for differentials by sex, the ratio of female to male pay is higher and increased more in economies with centralized wage-setting such as Sweden or with special centralized features such as Australia than in decentralized economies such as the U.S. (Gregory and Ho, 1985; OECD, 1985) Finally, differentials by age also changed across countries, steepening in the U.S. and some other countries with baby-boom induced increases in the supply of young workers, narrowing in Japan, which had a shortfall of youth, while remaining stable in countries with centralized wage-setting (Bloom and Freeman, 1986; OECD, 1984; Leroy, 1987). In short, the pattern of wage differentials along dimensions other than industry across countries is sufficiently similar to that in Industry differentials to make industry dispersion a reasonable indicator of differences in overall wage-setting systems.

When one contrasts specific countries with less pronounced institutional differences, however, these broad-based measures can be misleading. Consider, for instance, relative wage flexibility by geographic area in the US, which 
ranks low in unionism and high in dispersion in Tables 1 and 2 and is generally viewed as the archetypal flexible labor market and in the UK, which ranks in the middle of the unionism category and has a modestly narrower industry wage structure. As can be seen in Table 3 , in the US wages are high in areas of high unemployment and show little response to fncreases in unemployment whereas in the UK wages declined in the 1980 s in high unemployment areas. These patterns imply greater rather than smaller responsiveness of pay to area unemployment in the UK. Relative pay by skill and age also appear to have been no less flexible in the UK than in the US in the 1980s, with premium rising in both countries, as noted earlier. The implication is that while dispersion, union density, and other broad indicators of labor market institutions may accurately reflect gross differences between centralized and decentralized labor markets, they may not depict accurately differences in the operation of markets between specific countries. Caveat emptor.

comparing measures of labor market structure

This said, how closely linked are union density and industry dispersion to one another and to widely used indices of corporatism or other categorizations of labor market institutions?

As a first step to answering these questions I calculated correlation coefficlents between the union densities in table 1 and 1 ndustry wage dispersions in Table 2, obcaining values ranging from -0.30 to -0.56 , and calculated correlations between 1970-1980 changes in density and in 1973-84 changes in dispersion, obtaining a coefficient of 0.36 . The correlations show that wage dispersion contains information beyond that captured by union density, and conversely. Second, I compared dispersion and union density across countries according to widely used corporatist indices. Most countries classified by Colin Crouch (1985) as corporatist and, ipso facto, by Bruno and Sachs (1986), who rely on Crouch's work, have high union density and low wage 
Table 3: Regression Coefficlents and Standard Errors For the Relation of wages to Unemployment. by Area: US VS UK

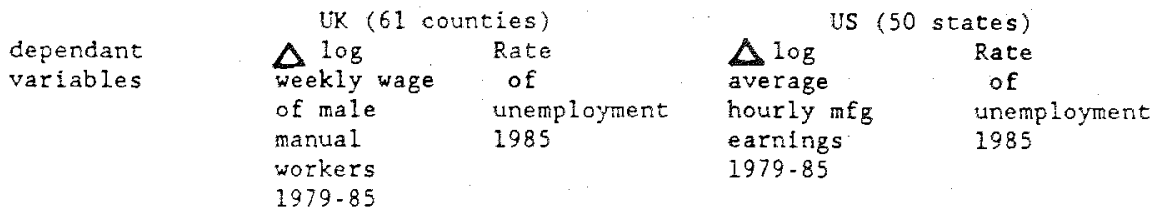

independant variables

$\Delta$ unemployment $\quad-.92$ rate (.27)

log wage/earnings

$-.43$

(.30)

1985

.03

.11

Other variables

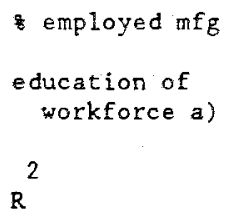

$\mathrm{R}$

Source: UK data from US data from US Statistical Abstract various editions.

Notes:

a) UK education measured by

US education measured by median years of schooling 
dispersion, producing a sizeable positive correlation between a corporatist dummy variable and density $(r-0.45)$ and a negative correlation between it and dispersion $(r=-0.47)$. Still, the relations are far from perfect: Belgium and Australia, rated low in corporatism, are high in unionism while 'corporatist' Austria has high wage dispersion. Third, I correlated union density in 1980 and industry dispersion in $1984 / 5$ with Calmfors and Driffills' ranking of countries by centralization of wage-setting and found that those at the top of their list (with low ratings) were more unionised $(r-0.71$ ) and had lower wage dispersion $(r-0.37)$. The relatively small correlation between wage dispersion and centralization is due to Austria, which they rank as number one in centralization while it has, as noted, high wage dispersion. (6)

The union density and dispersion of industry wage indlcators of labor market structures have three advantages over judgmental categorisations: they are based on 'hard' statistics; they vary over time in a natural way: and they lead one to look in close at actual wage outcomes and union representation. The disadvantage is that they are a step. removed from the corporatist/centralized wage setting and flexible market corcepts that underlie the debate over alternative labor market arrangements. As they have both advantages and disadvantages, In ensuing analyses. I use them and judgmental categorisations of institutions to indicate the nature of the labor market structures that may affect outcomes. First, however, it is necessary to delineate country differences in outcomes and examine the labor demand relation that constrains employment and wage outcomes.

\section{Outcomes and Constraints}

As the divergent views of American/European economic success given at the outset indicates, choice of outcomes is critical in comparing performance. One can get different pictures of economic performance by focusing on growth as opposed to levels of outcomes; selecting one indicator rather than another; 


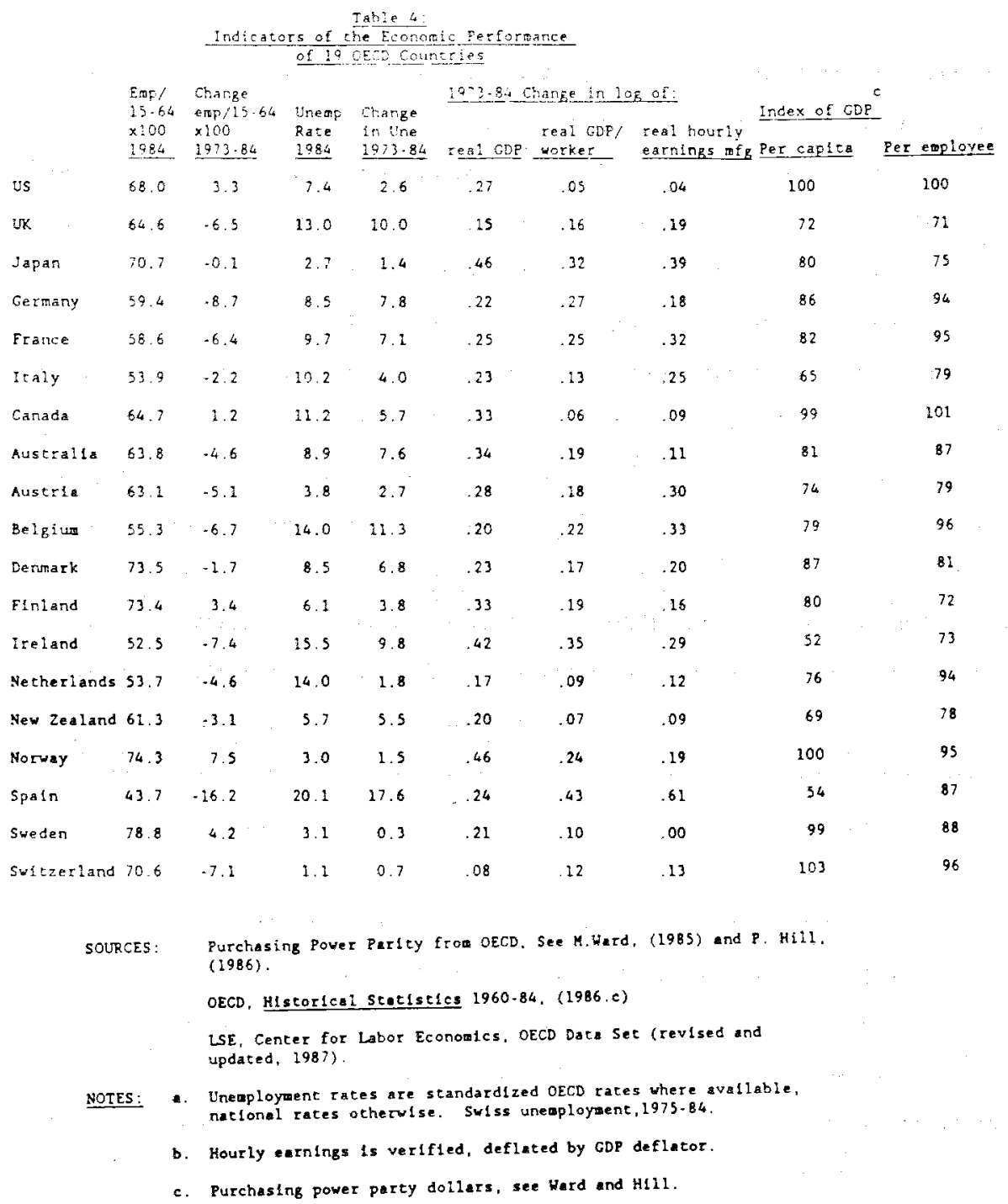


comparing changes over one period rather than another, and so on (e.g. "manufacturing productivity is rising rapidly in the U.K." versus "employment is below 1979 levels"). To deal with this problem I present in Table 4 data on levels and changes in several outcomes. Colums $1-4$ show the divergence in employment/working age population and unemployment rates among OECD countries that has attracted most attention. The unemployment figures document the shift of the U.S. from relatively high to relatively low unemployment while the employment/population ratios show the growth of employment in the US, Sweden and some other countries compared to the drop in the France, UK, Germany, among others. The colurn 5 evidence shows that despite differences in labor utilization, GDP did not increase that differently across countries. The 'reason' is indicated in column 6's change in labor productivity (GDP per employee) and column. 7 's change in real wages, which are inversely related across countries to growth of employment (compare US and Sweden with Belgium and UK). If one adjusts the productivity growth figures for the $1975-19864-98$ decline in annual hours worked in Europe compared to the US (OECD 1987), Inoreover, the difference in productivity growth between the US and OECD Europe becomes even more pronounced. One uncommon interpretation of the US-Europe experience in the 1970s-1980s is that Americans had to work more to obtain similar increases in living standard, and thus that high employment America did not perform as well as low employment Europe, save for workaholics.

Columns 8 and 9 turn to levels of performance. They contrast GDP per capita and GDP per worker across countries in OECD purchasing power parity units. These figures show greater similarity in GDP per worker than in GDP per capita, due to the fact that countries with low employment/population rates have correspondingly higher productivity. This presumably reflects increases In measured productivity as employment falls along production functions. Note also that, concern about Japanese productivity notwithstanding, GDP per worker 
is lower in Japan than in Europe and the US. As Americans (and Japanese) work more hours than Europeans (7), moreover, Europe looks even better in output per hour: British hourly output, for example, exceeded Japanese by 8 while French and German hourly outputs were virtually the same as American.

Erom the perspective of labor market analysis it is the relations between employment/unemployment performance and productivity/real wages in Table 4 that are most intriguing. In a period in which GDP growth did not differ greaty among countries (could not differ much because of economic and technological interdependence?) the differing performance of countries along these two dimensions raises the possibility that their economies faced similar wage/ employment trade-off schedules, of the sort often modelled by labor demand, though also explicable in other ways (Solow 1986), and thus that differences in employment reflect in part the position of countrles along that schedule.

\section{wage employment trade-off: aggregate evidence}

The standard method for analysing the fmpact of wages on employment across countries is to estimate time series demand relations for individual countries, and to use differences in estimated response parameters to account for differences in performances (e.g. the 1986 Unemployment Economica Supplement). My approach in this section is different. I take changes in wages and employment across countries (industries) over the same period rather than time series changes within a country as units of observation. I use the same equation for all countries, and thus attribute differing outcomes among countries to different changes in explanatory variables rather than to differing response parameters. To finesse issues of dynamic adjustments, moreover, I take changes over long periods.

Formally, my analysis can be represented by the following employment (demand) equation:

$d \operatorname{lnEc}=a d \ln W c+b d \ln K c+u c$, 
where $d \mathrm{ln}$ is the $\log$ change operator; $\mathrm{E}$ is employment; Wc are wages; $\mathrm{X}$ is a demand-shift variable; $u$ is a residual; the subscript $c$ indexes country.

If one assumes that each country has its own response parameters, a + ac and $b+b c$, where $a$ and $b$ are the mean responses and $a c$ and bc are the countryspecific components, then the latter are subsumed into the residual:

$$
d \ln E c=(a+a c) d \ln W c+(b+b c) d \ln X c+u c=
$$

a DlnWc + b DlnXc + ac DlnWc + bc DlnXc +uc,

where $a$ and $b$ are average response parameters.

In (2) heterogeneity in responses creates heteroskedastic errors but does not bias estimates of parameters as long as the country components are independent of the other variables in the equation. Material and related prices that are determined on world markets and whose changes are likely to be similar across countries are subsumed in the constant term:

\section{results}

Table 5 presents the results of estimating relations between changes in employment, real wages, and output for the entire economy in 19 OECD countries and for manufacturing in 12 countries over different time periods In panels A and $B$ the dependent variable is total employment, output is real GDP, and wages are manufacturing earnings (A) or compensation of employees from national product accounts per employee deflated by the GDP deflator (B); and changes are measured as In changes over the entire period. In Panel $C$ the dependent variable is total hours worked in manufacturing, output is value added in manufacturing, and wages are total compensation for manufacturing production workers deflated by GDP deflator; because the BLS publishes the data as compound annual changes, changes are measured in those units:

All three sets of calculations show that, conditional on the growth of output, changes in wages and employment were significantly inversely related. The US and Sweden, for example, with below-average real wage growth had above- 
Table 5: Regression Coefficients and Standard Errors For the Impact of Real Wages and Output on Employment

A) Dependent Variable: Change in $L_{n}$ Employment in period

$\begin{array}{llll} & \begin{array}{c}\text { Change in Ln } \\ \text { Real Wage }\end{array} & \begin{array}{c}\text { Change in } \\ \text { In GDP }\end{array} & \text { R2 } \\ 1960-73 & -.57(.11) & .62(.14) & .65 \\ 1973-79 & -.45(.11) & .71(.17) & .59 \\ 1979-84 & -.54(.15) & .52(.19) & .56\end{array}$

B) Dependent Variable: Change in Ln Employment in period

Change in In Real Change in

Labor Costs In GDP

$1960-73$

$-.76(.05)$

$.90(.07)$

$.75(.13)$

.94

$1973-79$

$-.62(.10)$

$.88(.22)$

.74

$1979-84$

$-.53(.16)$

.53

c) Dependent Variable: Compound Annual Change in Total Hours in $\mathrm{Mfg}$ In period

Compound Annual

Change in $\mathrm{Mfg}$

Compensation

$1960-73$

$1973-79$

$1979-85$
$-.53(.08)$

$-.89(.22)$

$-.75(.24)$
Compound Annual

Change in $\mathrm{Mfg}$ Output

$.62(.08)$

$.36(.22)$

$.80(.13)$
$\underline{\mathrm{R} 2}$

.86

.67

.81

Source: Panels $A$ and $B, 19$ OECD countries from CLE-OECD data set, as in table 4. Panel C, 12 Countries (US, Canada, Japan, France, Germany, Italy, UK, Belgium, Denmark, Netherlands, Norway, and Sweden) as given by A. Neef (1986), with wages deflated by GNP deflator, using OECD data. 
average growth of employment. Because rates of growth of GDP vary less than rates of growth of real wages, moteover, the wage-employment trade-off tells a greater part of the story of variation in employment performance across countries than do differences in rates of GDP growth although the latter are critical in explafning differences, as well.

By directly linking changes in employment and wages across countries, the calculations in Table 5 provide a potentially firmer basis for attributing differences in employment growth to differences in wage-settlements than timeseries regressions that rely on differences in estlmated response parameters of questionable robustness. St1li, one must take care in interpreting the results. With output fixed, the estimates neglect the 'scale' effect of wages on output and employment and thus may understate the employment consequences of wages. To gage the importance of this $I$ correlated changes in real wages and GDP across countries, obtaining positive coefficlents inconsistent with the notion that wage-induced output expansion is a major determinant of different country experiences. A second potential error arises because labor costs are a major share of value added, possibly producing a spurious negative employmentwage tradeoff (8). As regressions using industry data with gross output (where labor's share is small) or value added minus labor costs as the measure of production yield results similar to those in the table, I also doubt that this is a major problem. Finally, as Solow (1986) has stressed, there are other ways to interpret the observed wage-employment trade-off beyond wage-induced movements along demand curves. One such interpretation is in terms of the joint determination of wages and employment on an aggregate production function due to changes in GDP. As this implies a negative correlation between changes in GDP and wages, contrary to fact, I reject it as the primary explanation of the observed relations. Another possibility is that the trade-off reflects the impact of exogenous changes in productivity on real wages or on money wages and 
prices through both labor and product market behavior. thile I believe abserved cross-country differences in growth of output per worker are too large to represent longrun differences in technology among the countries, the problem of endogeneity of wages remains, for factors that influence wages (and the markup of prices over wages) are unlikely to be independent of growth of GDP and employment and unemployment. In sum, although none of the criticisms gainsays the empirical 'trade-off', they raise questions about its interpretation and meaning. To probe these issues I examine wage and employment changes with more disaggregate data.

industry evidence

There are three advantages to studying changes in wages and employment across disaggregated industries. First, it allows us to analyse employment and wages among industries within countries and thus to probe the postulated similarity of demand behavior that underlies equation 1 . Second, it offers ways to deal with the problem of endogeneity of output and prices by exploiting developments in foreign countries. Third, it makes the interpretation of the tradeoff as joint wage and employment determination along a production function less plausible, given the differing situations of specific industries.

Accordingly, I obtained data on wages, employment, value added, and production for 10 countries and up to 37 industries from an EEC file (9); and on employment, wages, value added and gross output in producers prices for up to 35 industries in 17 countries from the UN Yearbook of Industrial Statistics. The UN sample consists primarily of manufacturing industries, while the EEC data includes some other sectors. As in the country comparisons. I examine changes over long perfods.

alternative models

I use the following three equation model of price, output, and employment determination to analyse the industry data: 
Wage-Price Relation:

$$
\begin{aligned}
& \text { dlnPic - dlnPiw; } \\
& \text { dlnPic - vicdlnwic-dlnTic, }
\end{aligned}
$$

where $P$ is price; $v$ is labor's cost share; T represents neutral technological progress: i indexes industry; $c$ indexes country; and w indexes the world.

In (3A) the price in industry $i$ in country $c$ depends on world market prices and is thus exogenous to the labor market.

In (3B), by contrast, the price in an industry responds to wages according to labor's share in value added.

Which assumption is more plausible? For some industries and countries, prices are presumably largely exogeneous to the labor market because of international competition (or ocher reasons), for others, the opposite may be true. In the absence of a detailed pricing model, prudence dictates analysis of both.

$$
\text { Demand for Output: dlnQic - -y dlnPic + dlnXic, }
$$

where $y$ is the elasticity of product demand; and $x$ is a shift in demand for output in industry 1 in country c taken as exogenous.

Substituting 3B into 4 yields a relation between wages and output: dlnQic - yvdlnWic + ydlnTic + dlnxic. In $3 \mathrm{~A}$ wages have no impact on output.

Demand for Labor: dlnEic - -hdlnWlc + dlnXic + cdlnTic,

where the elasticity $h$ embodies substitution and scale effects; $X$ is an exogeneous shift due to shifts in product demand; I reflects technology.

The major problem with models of this type is the absence of measures of shifts in demand, which forces researchers to use actual output or instruments to proxy shifts. This creates problems due to the endogeneity of output through the production function and the uncertain quality of instruments. Cross-country data on the same industries allows us to treat the problem by decomposing the shift component into country-specific, industry-specific, and residual interaction effects: 
$d \ln T i c=d \ln T c+d \ln T i+v i c ; \quad d \ln X i c=d \operatorname{lnX} c+d \ln X 1+e i c$

Then, pooling industry and country data, one can use industry dumn variables to identify industry shifts (dniti and dlnXi) and country dumies to identify country shifts (dlnTe and dlnXc), eliminating endogenous output:

dlnEic = -hdlnwic $+D^{\prime}+C^{\prime}+$ residual,

where $D^{\prime}$ is a vector of industry dummies, $C^{\prime}$ is a vector of country dummies and the ic subscripts relate to industry and country respectively.

With two countries this is equivalent to comparing differences in changes in employment and differences in changes in wages. If labor demand behavior dominates the data, the country whose industry has a greater increase in wages will have a smaller increase in employment.

Alternatively, the change in Industry production in all countries can be used to proxy shifts in demand in an industry, ylelding:

$$
\text { dlnEic = -hdlnwic + edlnQi't } C^{\prime} \text {, }
$$

where Q' is the sum of production in industry in the countries under study. This equation asks "what is the impact of changes in wages on employment given world expansion of the industry, and employment trends in the country?" results

Analysis of the relation between changes in employment and wages by industry in the EEC and UN data sets confirms the existence of a significant wage-employment tradeoff across and within countries. Specifically:

(1) Regressions of changes in employment on changes in wages and output by industry within countries, summarized in appendix tables $A 1$ and $A 2$, yleld negative coefficients on wages of similar magnitudes among countries in both the EEC and UN data sets. The simflarity fustifies pooling the data into a single cross-country industry file in ensuing analysis. As wage-setting institutions are more likely to differ across countries than labor demand 
behavior, moreover, I interpret the results as reflecting similar demand elasticities rather than some other similarity in behavior.

(2) Whether one assumes that industry prices are exogeneously set on world markets or depend on industry wages in a country does not affect the inverse employment/wage relation. This is shown in the EEC regressions in table AI, where the regressions on the left hand side use wages and value added deflated by sector prices as explanatory variables (on the assumption that prices are determined on world markets) while the regressions on the right hand side use wages and value added in current values as explanatory variables (on the assumption that prices depend on wages). Both regresstons yield comparable negative coefficients on wages.

(3) Regression estimates of the impact of relative wages on employment using pooled country-industry data yield a significant inverse employment/wage relation when output is replaced by industry and country dumny variables or by 'world' output and country dumy variables. This is documented in Table 6 for the EEC (1ines 1-4) and UN (lines 5-8) data sets. Lines 1 and 5 give 'baseline' estimates from regression of changes in employment on changes in wages and output. Lines 2 and 6 give results when country and industry dunny variables have been added to allow for differences across countries and industries. Lines 3 and 7 show the results whenindustry output is excluded as endogenous. Here, the estimated elasticity falls rather than rises, possibly because industry-country specific technological or demand shifts lead to expanded production and higher wages as workers share in industry prosperty. Finally, lines 4 and 8 replace industry dummy variables with changes in output in the countries in the sample, with little effect on the estimates.

In sum, regardless of whether one uses domestic output, industry and country dumies or 'world' output to control for shifts in demand, the data reveal a substantial wage-employment trade-off in industries across countries. 
A. EEC Data Set

$$
\text { dlnw/Pic dinqic dingiw } \begin{gathered}
\text { Country Industry } \\
\text { Dummies }
\end{gathered} \mathrm{R}^{2}
$$

\begin{tabular}{|c|c|c|c|}
\hline 1 & $\begin{array}{r}-0.46 \\
(0.07)\end{array}$ & $\begin{array}{c}0.68 \\
(0.04)\end{array}$ & 0.65 \\
\hline 2 & $\begin{array}{r}-0.53 \\
(0.09)\end{array}$ & $\begin{array}{c}0.50 \\
(0.05)\end{array}$ & 0.83 \\
\hline & $\begin{array}{l}-0.30 \\
(0.11)\end{array}$ & & 0.69 \\
\hline , & $\begin{array}{l}-034 \\
(0.12)\end{array}$ & $\begin{array}{c}0.60 \\
(0.07)\end{array}$ & 0.55 \\
\hline
\end{tabular}

B. UN Data Set

$\begin{array}{cc}-0.50 & 0.61 \\ (0.05) & (0.02)\end{array}$

0.61

6. $\quad-0.60 \quad 0.54$

(0.07) (0.03)

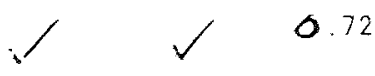

7. -0.33

(0.10)

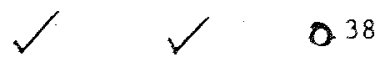

8. $\quad-0.22$

(0.12)

0.62

(0.05)

0.32

Note: All industry wages, value added, and gross output are deflated by country GDP deflator. 


\section{international competitiveness}

The pooled Industry-country data also allow us to examine the effects of exchange rates and unit labor cost on employment by regressing changes in employment on changes in wages, exchange rates (nominal units of currency per dollar) (10), and world output in an industry (measured in dollat terms) or industry dumies; and on changes in unit labor costs (wages $x$ employment/real value added), exchange rates, ard world output or industry dumies. As exchange rates are country-specific I replaced councry dumny variables with changes in country GDP to measure domestic market developments. I limit analysis to the EEC data because the UN data has no sectoral prices.

The estimated positive coefficients on exchange rates 1 in lines 1 and 2 of Table 7 indicate that, as one would expect, industries in countries where the currency depreclated relative to the dollar increased employment. The similar magnitudes of the wage and exchange rate coeffictents suggest, furthur, that wages have to change by roughly the same rate as exchange rates to offset currency fluctuations on employment. As labor is only part of costs, this may understate the required wage adjustment unless other costs move with wages.

Lines 3.4 yield very different results for unit labor costs, as declines in unit labor costs efther reduce (line 3) or have no effect (line 4) on employment. The 1mplication is that measure declines in unit labor costs, widely viewed as an indicator of increased competitiveness and thus something 'good', are more $11 \mathrm{kely}$ to reflect extensive shedding of labor than technological advance or wage declines that raise employment. Indicative of this, Ireland and Belglum, whose employment fell sharply, are anong the countrles with the greatest 'improvement' in unit labor costs.

To sum up, the evidence in this section reveals that the major differences in labor market performance among countries in the 1970 s and 1980 s $\cdots$ in employment and growth of real wages... were inversely related in a labor demand 
Tabie 7: Estimates of the Impact of Exchange Rates and Wages on Employment Growth Across Countries (EEC Data)

\begin{tabular}{|c|c|c|c|c|c|c|c|}
\hline & dlnw & dlnULC & $d \ln E R$ & dinGNP & dlnwvA & $\begin{array}{l}\text { Industry } \\
\text { Dummies }\end{array}$ & $\mathrm{p}^{2}$ \\
\hline 1. & $\begin{array}{r}-0.23 \\
(.08)\end{array}$ & & $\begin{array}{l}0.19 \\
(.06)\end{array}$ & $\begin{array}{c}0.12 \\
(.10)\end{array}$ & $\begin{array}{l}0.62 \\
(.09)\end{array}$ & & 0.33 \\
\hline 2. & $\begin{array}{r}-0.17 \\
(.06)\end{array}$ & & $\begin{array}{l}0.18 \\
(.05)\end{array}$ & $\begin{array}{l}0.05 \\
(.07)\end{array}$ & & & 0.65 \\
\hline 3. & & $\begin{array}{l}0.02 \\
(.05)\end{array}$ & $\begin{array}{l}0.09 \\
\langle .04\rangle\end{array}$ & $\begin{array}{l}0.73 \\
(.19)\end{array}$ & $\begin{array}{l}0.59 \\
.097\end{array}$ & & 0.34 \\
\hline 4. & & $\begin{array}{l}0.12 \\
(.05)\end{array}$ & $\begin{array}{l}0.07 \\
(.03)\end{array}$ & $\begin{array}{l}0.63 \\
(.14)\end{array}$ & & & 0.67 \\
\hline
\end{tabular}

Note : $W=$ earnings; ULC = unit labor costs, defined as (wages $x$ employment)/Value added in constant prices. ER = exchange rate in units of currency per dollar; GNP = Gross National Product in country; WVA = 'world value added' defined as sum of value added in industry in all countries in the data set. 
type trade-off. Countrles like the U.S. or Sweden where real wages increased slowly had more rapid growth of employment and higher employment-population rates than countries with rapid growth of real wages. While it is possible to interpret this finding in ways other than that suggested here, the trade-off represents the basic fact that any explanation of the divergence in outcomes must address.

\section{Insticutional Differences and Outcomes}

The question that arises next is whether the differences in outcomes across countries examined in section II are related to the labor market institutions examined in section I? Do countries with one set of institutions perform differently than countries with other institutions?

Extant empirical analyses offer, as noted, conflicting answers Some studies interpret the post oil-shock economic record as showing the success of 'corporatist' economies (Crouch, 1985; Bruno and Sachs 1986; Tarantel11 1986; Bean, Layard, and Nicke11,1986; Newe11 and Symons 1986). Others see better economic performances among countries with decentralized flexibility or with particular kinds of flexible labor market arrangements (Klau and Mittelstadt 1986; Freeman and Weitzman, 1986; Bruno and Sachs, 1986 with respect to nominal wage responsiveness).. The fallure of several follow-up analyses to confirm initial claims about the effect of institutions, seemingly because of modest differences in performance measures and periods covered (Van Poeck, 1987 ; Summers and Wadwhan1,1987; my calculations (11)); suggest the danger of generalizing from results based on a particular nodel and data set.

Accordingly, in this section I eschew estimating structural models of behavior under constraints in favor of 'reduced form' regressions designed simply to identify the links between indicators of labor market institutions and employment and wage outcomes... My analysis suggests that one reason for conflicting interpretations of the 1970 s-1980s experience is that there is an 
element of truth to both sides of the corporatist/flexible market debate: OECD countries with the most highly structured labor markets and those with the most decentralized labor markets turned in better employment performances than others. My analysis also reveals, however, a wide range of experience among countries with 'similar' institutions that suggests that even statistically significant and robust findings be interpreted with caution. empirical findings

Table 8 presents the results of regression estimates of the relation between labor market arrangements and employment and real wage outcomes in the 1980s. Lines $1-3$ are based on the OECD country data whilie lines 4 and 5 are based on the BLS data used in Table 5. In each calculation I relate outcome variables to: industry wage dispersion figures from Table 2 and the square of those figures, the 1979 percentage unionised from Table I, a $0-1$ corporatist dumny variable and the in change in output in the country. The key coefficients are those on dispersion, as they are designed to reflect the impact of both highly centralized (low dispersion) and decentralized (high dispersion) labor market arrangements on outcomes. If the two labor market structures produce similar outcomes, the equation will have a parabolic form, with linear and squared terms obtaining opposite signs in the regressions.

The regressions for employment/population in line 1 show that in fact this is the case for overall labor utilisation: the level of dispersion has a negative impact on employment while its square has a positive impact, indicating that increases in dispersion are first associated with falling then with rising employment/population rates, and thus that both countries with centralized and those with decentralized labor markets generated more employment than others. The unemployment regression in line 2 shows the same pattern with oppositely signed coefficients, as one would expect, though the parabolic form has less statistical significance. That the cross-section 
pattern is not simply the result of long-standing country differences in labor utilization is indicated by the coefficients on the dispersion terms in the change in employment/population regression in line 3. At least part of the 1984 cross-section differences result fron differential country responses to the 1980 s economic environment.

As for the other labor market indicators, the percentage union has modest generally insignificant effects on the three outcomes while the corporatist dunny obtains generally significant coefficients, indication that those economies did better in employment and unemployment, even with the levels of di persion and unionism held fixed. In all cases, finally, changes in output raised employment or reduced unemployment.

To provide a better picture of the parabolic pattern in the data and to show the variation among countries around fitted values. I graph in Figure 1 the predicted and actual 1984 employment/population rates against the level of dispersion. The figure shows the cross-country differences that underlie the regression results and the substantial variation around the regresston fit that leads me to be circumspect in drawing conclusions. In regressions with country observations residuals like those shown in the graph cannot be ignored on the principle that 'social science always has residuals': an aberrant country is a genuine counter-example (unlike an outlier in individual data files); and there are several in the scatter.

Turning to the BLS data, the regression in 1 ine 4 shows that changes in total hours in manufacturing is related parabolically to dispersion while having no connection to the other indicators of labor market structure. Line 5 shows the opposite relation between dispersion and changes in real compensation in manufacturing, with the level of dispersion entering with a positive coefficient and its square entering with a negative coefficient. This pattern implies that increased dispersion is associated first with rising, then 
Table 8: Regresston Coefficients and Standard Errors for Relation Between Indicators of Labor Market Structure and Employilent and Wages, 1979.85

Data set and

Dependent variables DISP DISP ${ }^{2}$ zUNION CORP $\Delta_{\text {output }} R^{2}$

OECD 19 Countries

1. Emp/15-64 1984

$0.26-0.07$

5.99

630

0.74

(2.82

$(0.07)$

$(0.08)$

(2.65)

(23.3)

2. Unemp, 1984

$\begin{array}{llllll}3.02 & -0.07 & 0.09 & -5.41 & -49.5 & 0.64 \\ (1.89) & (0.04) & (0.05) & (1.78) & (15.7) & \end{array}$

3. $\Delta_{\text {in Emp/pop, }}$

$-3.47 \quad 0.08$

$-0.03 \quad 3.98$

31.1

0.48 1979-84

$(2.13) \quad(0.05)$

$(0.06)$

(2.00)

(17.6)

BLS 12 Countries

4. Compound annual

$\begin{array}{llllll}-10.36 & 0.30 & -0.12 & 8.48 & 0.44 & 0.80 \\ (5.4) & (0.16) & (0.21) & (11.67 & (0.24) & \\ & & & & & \\ 11.3 & -0.39 & -0.08 & -4.28 & 0.44 & 0.60 \\ (4.70) & (0.14) & (0.19) & (10.1) & (0.21) & \end{array}$

. Compound annua Change in Hourly Compensation

Source:

DISP, lines $1-3$ based on UN data from table 2 with figures for Switzerland and the Netherlands proxied by Germany on the basis of the similarly shown in other data sets, and the figures on France estimated at 1 point below that in Germany in 1983 than Germany on the basis of figures reported by the Swedish Employers Federation, as given in Klau and Mittelstadt.

lines $4-5$ based on BLS data from table 2

with Ilo figure used for Norway (10)

Union, 1979 figures from table 1

CORP, $0-1$ corporatist dumny from Crouch (1985)

Notes:

a) All dependant variables multiplied by 100 so to reduce numbers of zeros in estimated parameters 
The Relation Between the Dispersion

of Earnings Acress Industries and Enployment/Population.

Employmenc/Eopulation 16-64

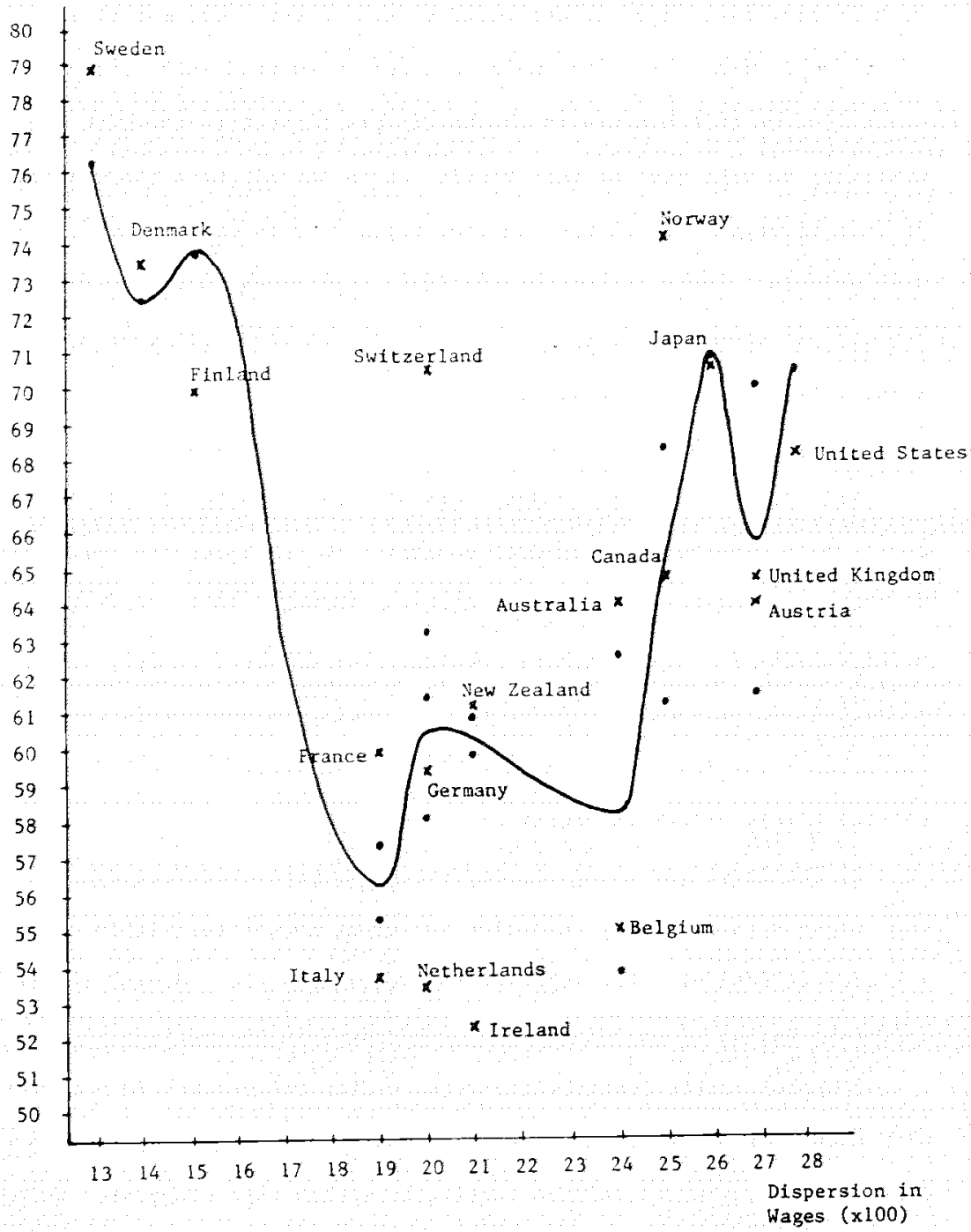

Where:

$x$ represents actual Employment/Population 16-64 (I/P)

- represents predicted E/P. (from Regression Equation) 
with falling real wage, as one would expect if the labor market institutions affect employment along the employment-real wage trade-off schedule. As I could find no such pattern in the hourly pay figures in the OECD data, I am unwilling to make much of this result. Even the BLS data show, moreover, greater divergence in changes in real wages than in employment across countries with 'similar' labor market institutions, suggesting that the existence of country differences in the real wage-employment trade-off that are subsumed in error cerms in our regressions.

\section{Summary}

This paper has four messages regarding labor market institutions, constraints, and outcomes in OECD countries in the 1970s and 1980s:

1) Labor market institutions diverged markedly in the period under study: union density increased in many countries but declined sharply in the Us and moderately in some others; industrial wage dispersion rose in several less unionised countries, Including the US, fell in Italy, while holding steady in several highly unionised countries.

2) The level and change in employment-to-population rates and change in real wages differed among countries and among industries within countries along a trade-off schedule that suggests that movements along demand curves were an important factor in the divergence in outcomes in the period.

3) Labor market institutions were related to outcomes in a nonlinear way, with countries having centralized institutions/low wage dispersion and countries having decentralized institutions/high wage dispersion doing better in limiting unemployment and maintaining employment than countries with intermediate labor market institutions.

4) There is sufficient diversity among countries with 'comparable' Institutions to indicate that desireable, or undesireable, outcomes are not the exclusive property of any single labor market arrangement, possibly because all 
have the potential for adopting the 'right' or 'wrong' policies to attain feasible outcomes.

Finally, it is important to recognize that the cross-country analys is in this and other studies leaves open the issue of 'exportability' of institutions - the extent to which labor market arrangments developed in one country can be transfered to others: Centralized corporatist labor markets are found primarily in small countries. Decentralized markets characterize larger economies. Perhaps, whatever its virtue, 'corporatist' wage-setting could not flourish in economies like the US or the UK as it does in Sweden and Denmark; and conversely for decentralized systems in smaller economic settings. If this is the case, the issue to be addressed in the future ought not to be which broad set of labor market arrangements 'work better' but rather which specific policies and programs work and can be transfered to other countries. 


\section{Endnotes}

1) There are several sources of data on unionisation: union reports of membership, enterpise reports on collective bargaining; household surveys; and union financial records. Among the problems with these different data are: the tendency for unions to exaggerate membership in some periods (recognized as a problem with U.K. statistics in the 1980s); lack of knowledge of collective bargaining status (by household recipients reporting on other recipients); unwillingness to make data public (in countries where dual unions compete). In the U.S. the Department of Labor terminated its survey of unions and now reports figures from houschold data.

2) In the case of France, figures on the proportion of workers covered by industry-level agreements suggest much higher union influence, while those on the proportion covered by plant-level agreements are consistent with the low density shown in the table. see Ministere du Travail 1986.

3) For example, the Workplace Industrial Relations Survey reports that the proportion of private manufacturing establishments with no recognized union rose from 35 to 448 between 1980 and 1984 (Millward and Stevens, 1986 p. 62) while the New Earnings Survey shows a fall in the percentage of male workers covered by collective bargaining from 74 in 1973 to 648 in 1984 .

4) Several points of caution here. First, it is possible for wage structures to change while wage dispersion remains fixed-- if for instance, high and low wage industries simply change position. As wage structures show persistence of rank order, however, this is not a serious problem. Second, wage dispersion could be high but all wages change in concert. This would show up in different orderings of countries by dispersion and dispersion of changes.

5) Calculations in which I sued the same number of industries for all countries did not alter any of the findings in the table. 
6) The calculations are based on relating the dispersion figures from the UN data to the union densities from table 1 . I made one slight modification in the Chalmfors and Driffill's ranking, giving Ireland the same ranking as the UK, while they left out. Ireland.

7) Annual hours worked: 2043 in Japan; 1888 in U.S.; 1723 in the U.K.; 1678 in Germany and 1630 in France, according to the OECD, 1986

8) If labor costs were all of value added, then ln employment would be perfectly negatively related to in wages, holding ln value added fixed, with a coefflcient of one.

9) This data set was provided to me by Ms. Dewatripont of the University of Bruxelles, whose work with $V$. Ginsberg and Dewatripont reveals a significant wage-employment tradeoff in time series analyses of these data for several European countries. (Ginsberg and Dewatripont, 1987)

10) It is appropriate in cross-country analysis to measure exchange rates and wages in nominal units as we are comparing changes in rates in one country relative to those in ocher countries.

11) I find no relation between indices of corporatism or nominal wage responsiveness and the outcome measures Crouch and Bruno and Sachs use in their analyses in the 1979.84 period. 


\section{Bibliography}

Bean, C. and P.R.G. Layard, and S.J. Nickell (1986) "The Rise in Unemployment: A Multi-country Study" Economica Unemployment Supplement 1986, S1$\mathrm{S} 22$

Be11, Linda and Richard Freeman (1985). "Does a Flexible Industry wage Structure Increase Employment?" NBER horking Paper 1604

Bruno, Michael and Jeffrey Sachs (1985) Economics of Worldwide Stagflation (Harvard Univ Fress, Cambridge Mass 1985)

Calmfors, Lars and Driffill, (this volume) "Centralization of Wage Bargaining and Macroeconomic Performance,"

Crouch, Colin (1985) "Conditions for Trade Union Wage Restraint" in L. Lindberg and C.S. Mail (ed) The Politics of Economic Stagflation (Washington DC Brookings 1985)

Freeman, Richard (1981), "The Changing Economic Value of Higher Education in Developed Economies: A Report to the OECD" NBER Working Paper 820, Dec. 1981

Freeman, Richard, and David Bloom (1986), "The Youth Problem: Age or Generational Crowding", National Bureau of Economic Research Working Paper No.201 1986

Freeman, R. and Martin Weitzman, (1986) "Bonuses and Employment in Japan". National Bureau of Economic Research Working Paper $\$ 8781986$. 
Ginsberg, Victor and Dewatripont, C. (1987) research in progress, University Libre de Bruxelles, Spring 1987

Gregory, Robert and Vivian Ho (1985) "Equal Pay and Comparable Worth: What can the U.S. learn from the Australian Experience" Discussion paper 123. Center for Economic Policy Research Australian National University July 1985

Hill, Peter (1986) "International Price Levels and Purchasing Power Parities," OECD Economic Studies no, 6, (Paris Spring 1986)

Klau, F. and Axel Mittelstadt (1986), "Labour Market Flexibility" OECD Economic Studies 1986

Leroy, R (1987) "Le Salaire Des Jeunes Est-Il Flexible?" Bulletin do L'Ires, University Catholique de Louvain, no 116, Mai 1987.

Millward, Neil and Mark Stevens (1986). British Workplace Industrial Relations 1980-84, Gower Publishing Company 1986

Ministere du Travall, De L'Emploi et de la Formation Professionelle, Tableaux Statistics Paris 1986.

A. Neef (1986) International Trends in Productivity, Labor Costs in Manufacturing", Monthly Labor Review, December 1986, Vol, 109, num. 12

A. Newell and J.S.V. Symons (1986), "Corporatism, Laissez-Faire and the Rise in Unemployment" Centre for Labour Economics, London School of Economics, Discussion paper 260, November 1986 
Organisation of Economic Cooperation and Development,

-... (1984) Employment Outlook, Paris Sept. 1984

-...-(1985) Employment Outlook, Paris Sept. 1985

-..-(1986a) Labour Market Flexibility París (May 1986)

-..-(1986b) Employment Outlook, Paris Sept. 1986.

-...(1986c) Historical Statistics, Paris 1986

.... (1987) Employment Outlook. Sept. 1987. Paris

Roche, W.K. and Joe Larragy (1987), "The Trend in Unionisation in the Republic of Ireland" in T Murphy et al Recent Trends in Irish Industrial Relations: A Reader (University College Dublin 1987)

Solow, R. (1986), "Unemployment:Getting the Questions Right" Economica Unemployment Supplement 1986, \$23-\$34

Summers, L and S. Wadhwani (1987), "Labor Cost Flexibility and Output Variability: Some International Evidence" mimeo 1987

Tarantelli, Ezio (1986), "Monetary Policy and the Regulation of Inflation and Unemployment" in Morley Gunderson, Noah Meltz, and Sylvia Ostry, ed Unemployment international perspectives (University of Toronto, 1986) 
Van Poeck, (1986), "Labour Market Characteristics, Stabilization Policy, and Real hage Flexibility" Studiecentrum Voor Economisch en Sociaal Onderzoek, Report $86 / 199$ oct 1986 Antwerpen

Ward, (1985) "Purchasing Power Parities and Real Expenditures in the OECD" (Paris, OECD, 1985). 
Appendix Table A1: Estinates of the Wage - Employment Relations by Country Across Induscries

EEC Data $1970-83$

$0 m-5 \cot 0 \mathrm{r}$ Deflator

\begin{tabular}{|c|c|c|c|c|c|c|}
\hline $\begin{array}{l}\text { ombery } \\
\text { squared }\end{array}$ & $\operatorname{dinh} / \mathrm{P}$ & dlnVA & $2^{2}$ & $\operatorname{din} w / P$ & dinva & $R^{2}$ \\
\hline United States & $\begin{array}{c}-0.82 \\
(0.07)\end{array}$ & $\begin{array}{c}0.89 \\
(0.07)\end{array}$ & 0.91 & $\begin{array}{l}-0.78 \\
(0.16)\end{array}$ & $\begin{array}{c}0.86 \\
(0.06)\end{array}$ & 0.90 \\
\hline Japan & $\begin{array}{c}-0.79 \\
(0.12)\end{array}$ & $\begin{array}{c}0.79 \\
(0.13)\end{array}$ & 0.66 & $\begin{array}{l}-0.72 \\
(0.27)\end{array}$ & $\begin{array}{c}0.78 \\
(0.12)\end{array}$ & 0.66 \\
\hline Germany & $\begin{array}{l}-0.69 \\
(0.11)\end{array}$ & $\begin{array}{c}0.66 \\
(0.08)\end{array}$ & 0.83 & $\begin{array}{l}-0.68 \\
(0.33)\end{array}$ & $\begin{array}{c}0.67 \\
(0.07)\end{array}$ & 0.82 \\
\hline France & $\begin{array}{c}-0.47 \\
(0.12)\end{array}$ & $\begin{array}{c}0.86 \\
(0.16)\end{array}$ & 0.61 & $\begin{array}{l}-0.61 \\
(0.29)\end{array}$ & $\begin{array}{c}0.57 \\
(0.14)\end{array}$ & .0 .50 \\
\hline Italy & $\begin{array}{l}-0.56 \\
(0.12)\end{array}$ & $\begin{array}{c}0.63 \\
(0.16)\end{array}$ & 0.51 & $\begin{array}{c}-0.49 \\
(0.17)\end{array}$ & $\begin{array}{c}0.64 \\
(0.15)\end{array}$ & 0.51 \\
\hline United Kingdom & $\begin{array}{l}-0.63 \\
(0.18)\end{array}$ & $\begin{array}{c}0.61 \\
(0.11)\end{array}$ & 0.66 & $\begin{array}{l}-0.74 \\
(0.38)\end{array}$ & $\begin{array}{c}0.55 \\
(0.11)\end{array}$ & 0.60 \\
\hline Netherlands & $\begin{array}{l}-0.34 \\
(0.17)\end{array}$ & $\begin{array}{c}0.86 \\
(0.18)\end{array}$ & 0.76 & $\begin{array}{l}-0.66 \\
(0.32)\end{array}$ & $\begin{array}{c}0.63 \\
(0.11)\end{array}$ & 0.69 \\
\hline Belgium & $\begin{array}{l}-0.57 \\
(0.15)\end{array}$ & $\begin{array}{c}0.65 \\
(0.13)\end{array}$ & 0.61 & $\begin{array}{l}-0.36 \\
(0.39)\end{array}$ & $\begin{array}{c}0.64 \\
(0.12)\end{array}$ & 0.61 \\
\hline Denmark & $\begin{array}{c}-0.90 \\
(0.13)\end{array}$ & $\begin{array}{c}0.79 \\
(0.11)\end{array}$ & 0.73 & $\begin{array}{l}-1.25 \\
(0.20)\end{array}$ & $\begin{array}{c}0.75 \\
(0.10)\end{array}$ & 0.78 \\
\hline
\end{tabular}

Note: W is earnings; VA is valued added, as given in the EEC data set. 


\section{Appendix Table A2: Estimates of the Wage-Employment Relation by Country, Across Industries, \\ UN Data 1973-83.}

Country

$\mathrm{dlnw} \quad \mathrm{dlnGO} \quad \mathrm{R}^{2}$

United States

$\begin{array}{ll}-0.78 & 0.61\end{array}$

0.73

$(0.23)$

$(0.07)$

Japan

$$
-1.11 \quad 0.36
$$

$(0.23) \quad(0.06)$

Germany

$$
-0.36
$$

0.60

$(0.37) \quad(0.05)$

Italy

$-0.53$

0.57

$(0.15) \quad(0.07)$

United Kingdon

$-0.62$

0.78

0.93

$(0.32)$

$(0.04)$

Netherlands

$-1.08 \quad 0.54$
0.15

0.84

$(0.15)$

$(0.17)$

Denmark

$-0.35 \quad 0.68$

$(0.60) \quad(0.12)$

Ireland

$-0.53 \quad 0.48$

$(0.39) \quad(0.06)$

Australia

$-0.34$

$$
(0.15)
$$

0.70

0.63

Austria

$$
-0.47
$$$$
\text { (0.10) }
$$

0.59

$(0.28) \cdots(0.07)$

Canada

$\begin{array}{lll}-0.26 & 0.57\end{array}$

(0.24) $\quad 0.06$

Finland

$$
\begin{array}{ll}
-2.03 \quad 0.38
\end{array}
$$

$(0.61) \quad(0.08)$

Norway

$-0.53$

0.89

$(0.38) \quad(0.03)$

New Zealand

$$
1.05
$$

(0.69)

0.74

(0.11)

Sweden

$$
\begin{array}{cc}
-0.66 & 0.60 \\
(0.70) & (0.06)
\end{array}
$$

0.73

0.85

0.80

Note: $W$ is the ratio of wage and salary bill to employees while $G 0$ is gross output. 